\title{
Short Communication / Nota Científica \\ Two new records for Bromeliaceae in the central-west region of Brazil: Vriesea friburgensis and Tillandsia polystachia
}

\author{
José Herlânio de Lima $^{1,2}$ \& Lucia Helena Soares-Silva ${ }^{1}$
}

\begin{abstract}
This study presents the first records of Vriesea friburgensis and Tillandsia polystachia for the central-west region of Brazil. The two species were found in gallery forests of the National Forest of Brasília, Distrito Federal. This conservation unit is located in the core region of the Cerrado domain. This finding extends the number of species of flora of this locality and of the Central-west Region, and also increases the area of distribution of the two species, previously restricted to the northeast, southeast and south of Brazil.

Key words: Cerrado, Distrito Federal, gallery forest, Tillandsia polystachia, Vriesea friburgensis.

Resumo

Este estudo apresenta os primeiros registros de Vriesea friburgensis e Tillandsia polystachia para a região centro-oeste do Brasil. As duas espécies foram encontradas em matas de galeria da Floresta Nacional de Brasília, Distrito Federal. Esta unidade de conservação está localizada na região nuclear do domínio Cerrado. Esta descoberta amplia o número de espécies da flora desta localidade e da região centro-oeste, além de aumentar a área de distribuição das duas espécies, anteriormente restrita ao nordeste, sudeste e sul do Brasil. Palavras-chave: Cerrado, Distrito Federal, mata de galeria, Tillandsia polystachia, Vriesea friburgensis.
\end{abstract}

Bromeliaceae has several distinct characteristics that distinguishes the family from other Angiosperms, having achieved a remarkable degree of morphological and ecological variation, therefore being considered a "climax" group (Dahlgren et al. 1985; León \& Sagástegui (2008); Givnish et al. 2011). With the exception of Pitcairnia feliciana (A. Chevalier) Harms \& Mildbraed that is found in the Republic of Guinea, West Africa (Porembski \& Barthlott 1999), Bromeliaceae are found only in the New World, with distribution from southern United States (eastern Virginia) to Tierra del Fuego (Dahlgren et al. 1985; Givnish et al. 2011). According to Luther (2012), Bromeliaceae includes 3352 species and 58 genera. Brazil and the Distrito Federal account for 1307 and 22 species, respectively (BFG 2015).

Of the three most numerous genera of the family: Tillandsia, Pitcairnia and Vriesea, with 622, 342 and 281 species, respectively (Luther 2012), only the third is not cited for the Distrito FederalDF (BFG 2015). Thus, this is the first record of the genus Vriesea for this locality, represented by V. friburgensis Mez. A new record for Tillandsia polystachia (L.) L., is also presented, the first for the Distrito Federal. It is important to note that this is also the first record of these species for the central-west region of Brazil (BFG 2015).

This study was carried out by means of a floristic survey in gallery forests (sensu Ribeiro \& Walter 2008) on the banks of the Currais stream, in the National Forest of Brasilia, Distrito FederalDF (FLONA-DF), where the two species were collected. This conservation unit is located in the "core" region of the Cerrado domain, at the geographic coordinates $15^{\circ} 47^{\prime} 31^{\prime \prime} \mathrm{S}, 48^{\circ} 03^{\prime} 29^{\prime \prime} \mathrm{W}$ (headquarters of the conservation unit). The climate is Aw of Köppen's classification, with average rainfall of $1651 \mathrm{~mm}$, and minimum and maximum temperatures of $12^{\circ} \mathrm{C}$ and $33.4^{\circ} \mathrm{C}$, respectively, according to data from INMET (2012) for the last three years. The coordinates and the approximate elevation of the collection site are: $15^{\circ} 47^{\prime} 27^{\prime \prime}$, $48^{\circ} 05^{\prime} 22^{\prime \prime} \mathrm{W}$ and $1180 \mathrm{~m}$.

\footnotetext{
${ }^{1}$ Universidade de Brasília, Depto. Botânica-IB, Campus Darcy Ribeiro, C.P. 04457, Asa Norte, 70.904-970, Brasília, DF, Brazil.

${ }^{2}$ Author for correspondence: jhlimacoffeholic@gmail.com
} 
The procedure employed in the present floristic survey was that of trekking (Filgueiras et al. 1994), with biweekly field expeditions between July 2012 and June 2013. Fertile specimens of individuals found in the study area were collected. Sterile specimens and those, which possibly could be difficult to locate posteriorly, were collected and cultured until flowering in a greenhouse of the Centro de Recuperação de Áreas Degradadas, Universidade de Brasília (CRAD/UnB). The material was herborized according to IBGE (1991), and subsequently deposited in the herbarium of the University of Brasília (UB). Permission to collect botanical material was granted by the Chico Mendes Institute of Biodiversity (ICMBio) authorization number 33212-1 of 09/03/2012 and valid until 09/12/13.

The collected specimens were compared with material deposited in the herbaria of the Distrito Federal: UB, CEN, HEPH and IBGE (acronyms according to Thiers [continuously updated]), having been established that these species had not been deposited in this locality. Specialized bibliography was consulted with the description of two species to allow for correct identification (Reitz 1983; Pontes \& Agra 2006; Fiorato 2009; Coffani-Nunes et al. 2010; CONAP 2010; Coser et al. 2010; EspejoSerna \& Ramírez-Morillo 2010; Kremer 2011), just like the original description and holotypus of each species, when avaliable. Specimens deposited in other Brazilian and foreign herbaria were consulted in Specieslink (2015), Mobot (2015) and Paris (2015). The terminology used in the descriptions is according to Radford et al. (1974), Weberling (1992) and Gonçalves \& Lorenzi (2011). The distribution maps were drawn with the Quantum GIS 2.4.0 software using coordinates obtained in Specieslink (2015).

Vriesea friburgensis (Fig. 1) is a perennial, terrestrial, saxicolous and epiphytic herb growing from the level sea up to 1,500 m of altitude (Reitz 1983), and is distributed throughout Bolivia, Brazil, Argentina and Paraguay (Govaerts et al. 2010). In Brazil, it is found in the states of Pernambuco, Bahia, Espírito Santo, Minas Gerais, Rio de Janeiro, São Paulo, Paraná, Santa Catarina and Rio Grande do Sul (Martinelli et al. 2008; BFG 2015).

According to Wanderley \& Martins (2007), the species is part of a species complex requiring revisional studies to better define the division of each of the component species. These species are: V. procera (Mart. ex Schult. \& Schult. F.), V. neoglutinosa Mez, V. trilingulata Mez, V. rastrensis
Leme and $V$. thyrsoidea Mez. Vriesea friburgensis is also close to $V$. baturitensis Versieux \& Tomaz, but the latter species differs from the former by presenting smaller flowers and primary bracts yellow Versieux et al. (2013).

In this study we chose to follow the taxonomic treatment by Smith (1952) and Wanderley \& Martins (2007) who, after taxonomic and field studies, consider the species valid without dividing it into varieties.

In the study area, $V$. friburgensis was found only in a very restricted part of the gallery forest. The few individuals found were epiphytic and grew only on the southern edge of the forest.

The species is characterized by a height between $0.5 \mathrm{~m}$ and $1 \mathrm{~m}$; leaves ligulate, mucronate $30-50 \times 3.5-6 \mathrm{~cm}$, green to vinaceous; inflorescence racemose, composed $0.5-1.35 \mathrm{~m}$, reddish; primary bracts reddish; floral bracts shorter than the sepals, yellow; flowers distichous, ca. $4.5 \times 0.6 \mathrm{~cm}$, yellow; sepals ca. 3-3.5 $\times 0.8-1.1 \mathrm{~cm}$; petals 4-4.5 $\times 0.4-0.8 \mathrm{~cm}$; stamens exserted, adnate to petals, yellow; ovary almost pyramidal; style ca $4.5 \mathrm{~cm}$; stigma softly expanded.

Examined material: BRAZIL. DISTRITO FEDERAL: Taguatinga, Floresta Nacional de Brasília, 29.IX.2012, flowered in cultivation on 29.I.2013, J.H. Lima 12 (UB). Additional examined material: BRAZIL. BAHIA: Abaíra, Campo de Ouro Fino (baixo). 10.I.1992, fl., R.M. Harley et al. 50726 (NY); Rio de Contas, Pico das Almas, vertente leste. 27.XII.1988, fl., R.M. Harley 27434 (MO). MINAS GERAIS: Caldas, 13.XI.2009, fl., A.E.M. Rosa 17 (UEC); PARANÁ: Paranaguá, Ilha do Mel, Ponta Oeste, 22.XI.1986, fl., R.M. Britez, 24548 (UEC); RIO DE JANEIRO: Nova Friburgo, fl., A. Glaziou 16.467 (Holotypus P); RIO GRANDE DO SUL: Santa Maria, Arredores da cidade, s/d, fl., T.B. Breier 1228 (UEC); SANTA CATARINA: São Martinho, Chicão, 26.I.2010, fl., J.L. Schmitt et al. 1044 (FURB); SÃO PAULO: Cananéia, Parque Estadual da Ilha do Cardoso, Trilha da parcela, 08.XII.2002, fl., T.B. Breier, \& A.C.B. Breier 749 (UEC); Capão Bonito, Fazenda Intervales, 27.II.1990, fr., L.C. Passos 23125 (UEC); Sete Barras, Parque Estadual Carlos Botelho, Trilha da figueira, núcleo Sete Barras, 14.II.2002, fl., T.B. Breier \& A.C.B. Breier 781 (UEC); Ubatuba, Planície litorânea de Picinguaba, Trilha das Três Lagoas, Mangue 28.II.1996, fl., M.D. Moraes 300 (UEC).

Literature from the last ten years has limited the distribution of $V$. friburgensis to the eastern part of Brazil, in the northeastern, southeastern and southern regions (Versieux \& Wendt 2006; Martinelli et al. 2008; BFG 2015). However, there is some disagreement among these authors regarding the occurrence of this species in the states that make up these regions. 
The occurrence of this species in the Brazilian central-west contrasts with collections referenced in the literature, with the additional material examined and with data from collections obtained in Specieslink (2015). According to these sources, V. friburgensis is distributed mainly in the southern part of the Atlantic Forest. Its occurrence in the Caatinga, rocky fields
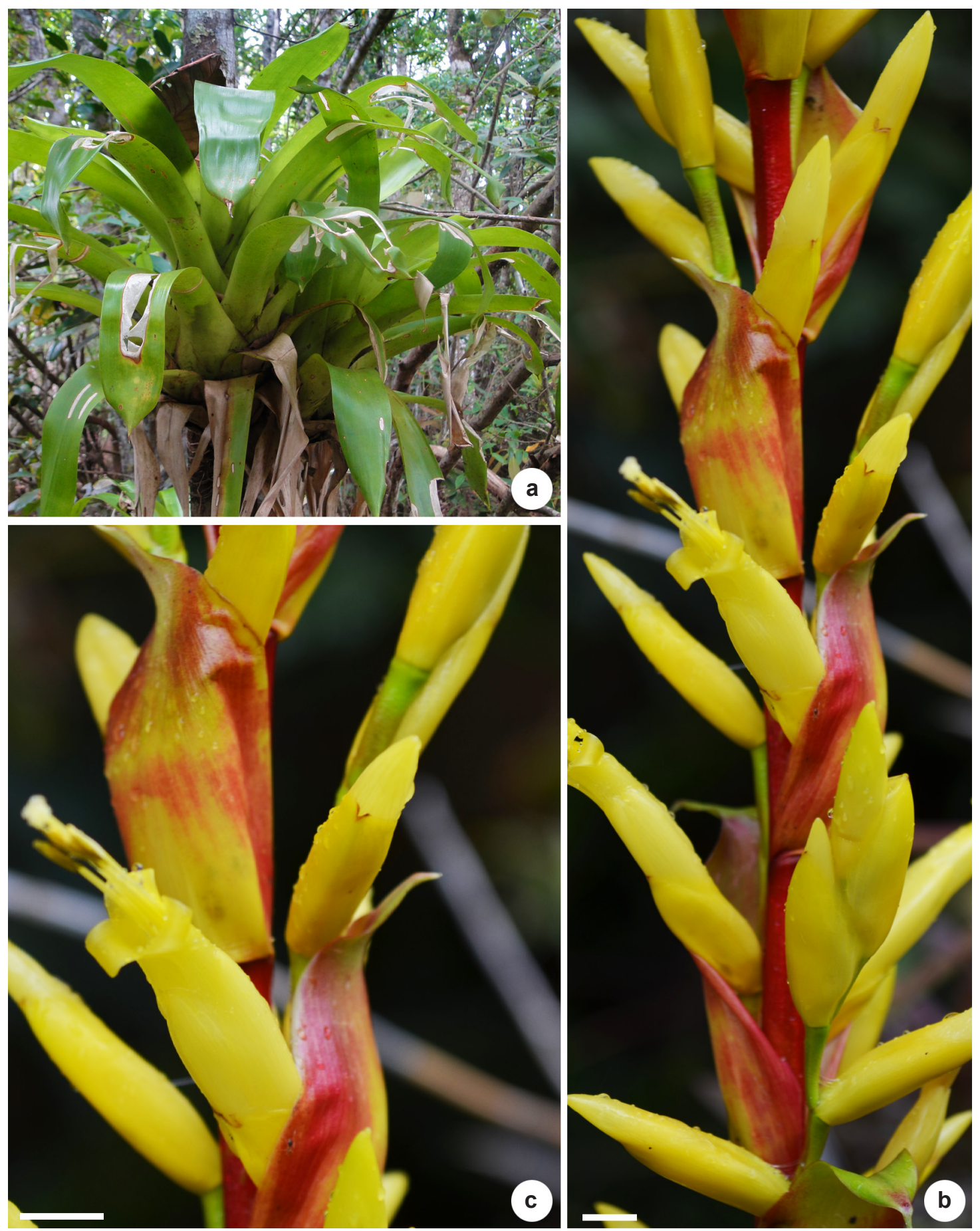

Figure 1 - Vriesea friburgensis Mez. - a. plant in habitat; b. inflorescence; c. flower (detail). a-c (J.H.Lima 12 - UB). Scale Bars $=1 \mathrm{~cm}$. (Photos: J.H. Lima). 
and Cerrado is incipient and only where these vegetations border the Atlantic Forest (Fig. 3). The collection of $V$. friburgensis in the Distrito Federal extends its distribution limits by about
$500 \mathrm{~km}$ towards the interior of the country, in relation to the nearest most recent record in Pedregulho, state of São Paulo (E.E. Machado 2690 - SPSF).
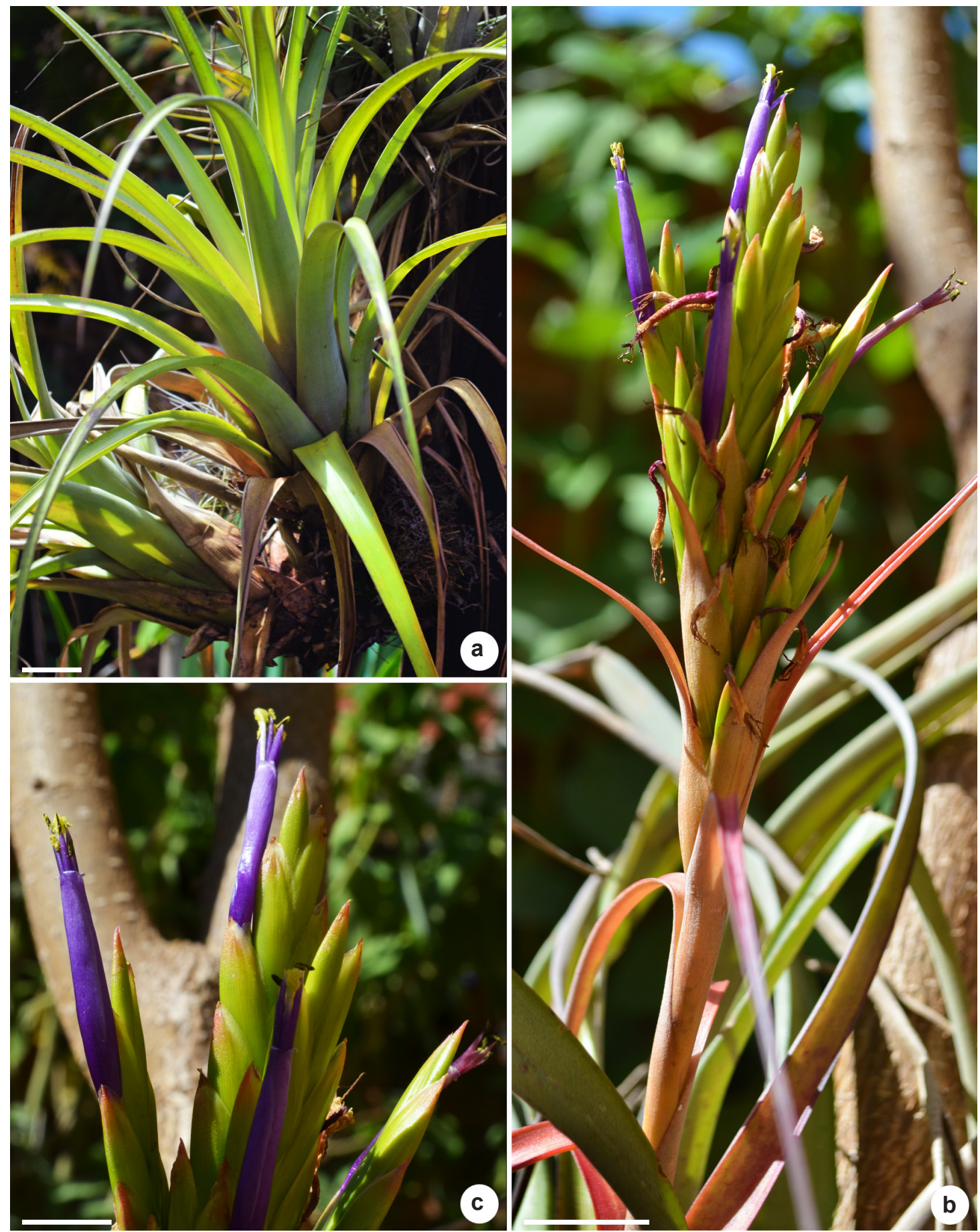

Figure 2 - Tillandsia polystachia (L.) L. - a. habit; b. inflorescence; c. flower (detail). a-c. (J.H.Lima 30 - UB). Scale bars: $\mathrm{a}=3 \mathrm{~cm} ; \mathrm{b}=2 \mathrm{~cm} ; \mathrm{c}=1 \mathrm{~cm}$. (photos: J.H. Lima). 
The occurrence of $V$. friburgensis in the core region of the Cerrado domain is only possible because of the protection provided by the gallery forests in this region that maintain a high humidity, even in the driest months, thus enabling the establishment of epiphytes (Ribeiro \& Walter 2001). The connection between the Cerrado gallery forests and the Atlantic Forest domain in a northwest-southeast route (Oliveira-Filho \& Ratter 1995) and the floristic similarity between this phytophysiognomy and the Atlantic Forest (Felfili et al. 2001), could explain the occurrence of this species in the Cerrado. Some characteristics of the seeds of this species may also have contributed to its establishment in the Cerrado: feathery appendages for anemochoric dispersal and the presence of phenolic compounds to withstand harsh micro-habitats for the establishment of seedlings (Prado et al. 2014).

Tillandsia polystachia (Fig. 2) is an epiphyte with distribution throughout Mexico, Central America, Ecuador, Venezuela, Bolivia, Brazil and Colombia (Govaerts et al. 2010). In the Brazilian territory, it is found in the states of Ceará, Paraíba, Pernambuco, Alagoas, Bahia, Minas Gerais, Espírito Santo, Rio de Janeiro, São Paulo and Paraná (Martinelli et al. 2008; BFG 2015).

The current literature is not passive regarding the taxonomic circumscription of $T$. polystachia and T. parvispica Baker. The original description of T. parvispica (Baker 1887) fits into other

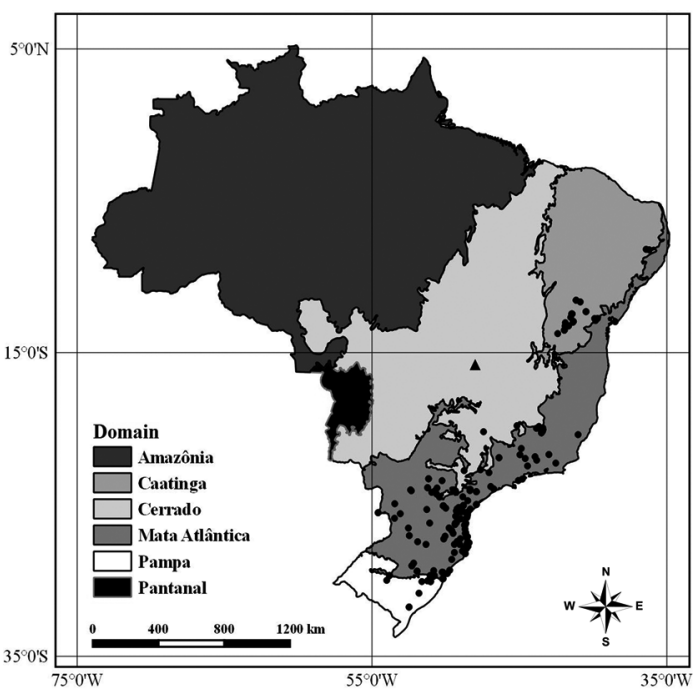

Figure 3 -Distribution of Vriesea friburgensis Mez.(•) on Brazilian territory based on data from Specieslink (2015) and the new occurrence for the Distrito Federal $(\boldsymbol{\Delta})$. descriptions of $T$. polystachia. Characteristics such as leaf and apex curvature; scape size and position on the leaves are also variable, so that the specimens of T. polystachia examined herein are very similar to those of T. parvispica. It is important to note that the Holotypus (A. Glaziou $13258 \mathrm{P}$ !) and the Isotypus (A. Glaziou 16452 $\mathrm{P}$ !) of this species were originally identified as T. polystachia. According to Siqueira-Filho et al. (2006 apud Fiorato 2009), it is possible to recognize two taxa: on the one hand, T. parvispica, including T. pfisteri Rauh, in Brazil and, on the other hand, the typical T. polystachia, in Central America and North America. However, studies using scanning electron microscopy of leaf scales of the two species showed no differences between the two taxa as they both have the same pattern, which is very characteristic and only observed in these two taxa, leading to the conclusion that we are dealing with a single species. For these reasons, and based on the literature and voucher specimens consulted, we will treat the species collected in the Distrito Federal as T. polystachia. The above arguments reinforce the decision for adopting this taxonomic treatment.

In the FLONA-DF, the species is very common and found in several parts of the interior of studied forest, always inside the forest.

Tillandsia polystachia is characterized by a height of 30-60 $\mathrm{cm}$, rosette utriculose; leaves triangular-lanceolate, $30-45 \times 2.5-4.5 \mathrm{~cm}$ cinereous-green, apex long attenuate; inflorescence congested, 20-40 cm long; primary bracts triangular, apex long attenuated, rose; floral bracts imbricate, green; flowers short pedicellate, ca. $5 \mathrm{~cm}$ long; sepals $1-1.6 \times 0.4-0.6$, green; petals $3.8-4.5$, violet; stamens exserted, ca. $4.5 \mathrm{~cm}$ long, violet; ovary ellipsoid, ca. $0.8 \mathrm{~cm}$, style ca. $4 \mathrm{~cm}$ long, stigma spiraled.

Examined material: BRAZIL. DISTRITO FEDERAL: Taguatinga, Floresta Nacional de Brasília, 14.X.2012, J.H. Lima 13 (UB); Taguatinga, Floresta Nacional de Brasília, 14.X.2012, J.H. Lima 14 (UB). Taguatinga, Floresta Nacional de Brasília, 24.V.2012, flowered in cultivation on 31.VIII.2013, J.H. Lima 30 (UB).

Additional examined material: BRAZIL. ESPÍRITO SANTO: Cachoeiro do Itapemirim, Fazenda Cafundó, 16.VIII.1999, fl., Martinelli et al. 15748 (VIES); PARAÍBA: Agreste, 11.XII.1958, fl., J.C. Moraes 2006 (NY); RIO GRANDE DO NORTE: Ceará-Mirim, 01.I.2008, I.B. Lira (UFRN); SÃO PAULO: Campinas, Fazenda Atalaia, Souzas, IX.1995, fl., I. Sazima 35348 (UEC); Campinas, Fazenda Atalaia, Souzas, 30.I.1994, M. Sazima, \& I. Sazima 31028 (UEC); SERGIPE: 
Nossa Senhora da Glória, Assentamento Adão Negro, 15.II.2011, fl., T. Carregosa 78 (ASE); DOMINICAN REPUBLIC. PROVINCE OF DUARTE: El Jojoban, on road to Castillo, 13.VIII.1981, fr., T. Zanoni et al. 16117 (NY); MEXICO. SAN LUIS POTOSI: 21.VI.1892, fl., C.G. Pringle 4106 (MO); CHIAPAS: Ixtacomitán, 08.III.1983, fl., T.P. Ramamoorthy et. al. 1809 (MO); NICARAGUA. DEPARTAMENT OF ESTELI: San Nicolás, 23.IX.1981, fl., P.P. Moreno 11389 (MO).

Data accessed in the current study allow us to infer that the distribution of T. polystachia in Brazil is concentrated in the transition region between the Caatinga and the Atlantic Forest. Of the few collections carried out in the Cerrado all, except for one, occurred in rocky fields bordering of the Atlantic Forest (Fig. 4). The collection carried out in the Distrito Federal enabled us to place the occurrence of this species in the core region of the Cerrado domain, $300 \mathrm{~km}$ from the most central previously recorded occurrence (F. França 3737 HUEFS) in Jaborandi, state of Bahia. We believe that the occurrence of $T$. polystachia in the core region of the Cerrado is due to anemochoric dispersal of the species and its ability to colonize habitats in forested areas, on rocky fields and in the Caatinga.

This study recorded two new occurrences of the species in Brazil: Rio Grande do Norte (I.B. Lira - UFRN) and Sergipe (T. Carregosa 78 - ASE). These new occurrences are not cited

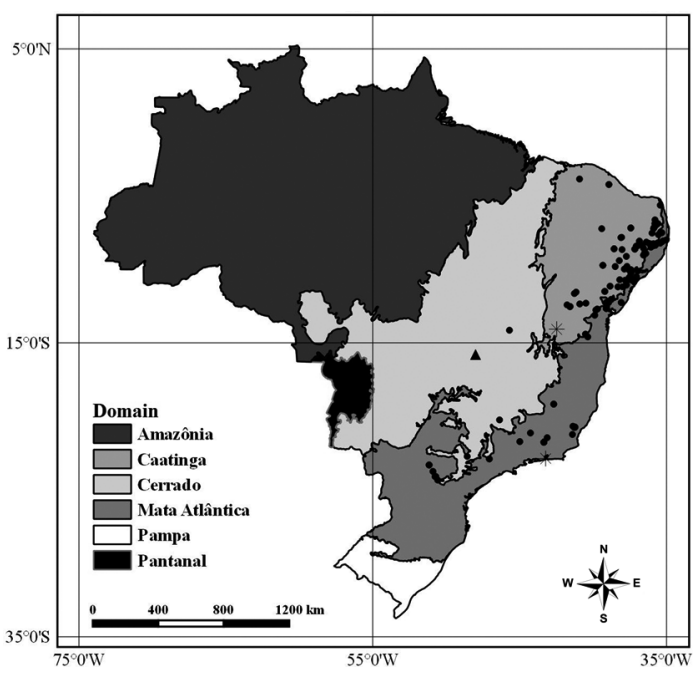

Figure 4 - Distribution of Tillandsia polystachia (L.) L. (•) and Tillandsia parvispica Baker (*) on Brazilian territory. The new occurrence of $T$. polystachia for the Distrito Federal is also indicated $(\boldsymbol{\Delta})$. by Versieux \& Wendt (2006), Martinelli et al. (2008) and BFG 2015.

We had access to only two occurrences of T. parvispica: A. Glaziou 13258 (P) and Glaziou 16452 (P), both from Boa Vista, state of Rio de Janeiro; J. Carneiro 1555 (ALCB), Caetité, state of Bahia. These few collections of T. parvispica occurred in areas close to those where $T$. polystachia was collected.

Smith \& Downs (1977) reported the species for the states of Acre (without an exact location on the material examined) and Mato Grosso, in the cities of Humaitá (which is in fact located in the state of Amazonas) and Campo Grande (today in the state of Mato Grosso do Sul). These occurrences should be better studied, since we were not given access to this material.

Although $T$. polystachya be widely distributed in the Americas and in the transition between Caatinga and Atlantic Forest, this is the first time that the species is recorded for the core region of the Cerrado, as well as for the centralwest region of Brazil. In turn, the Vriesea genus, that has about 30 species in the rocky fields of the Cerrado, had not yet been collected in the core region of the Cerrado. In the central-west region of the country this genus is represented only by $V$. heliconioides (Kunth) Hook. ex Walp, but in the Amazonia domain (BFG 2015). Thus, the present work presents the first record of Vriesea friburgensis to the core region of the Cerrado and the Brazilian central-west region. These new data suggest that there are knowledge gaps for bromeliads for the Distrito Federal, central-west region and the core region of the Cerrado.

These species are not listed as endangered species, according to Martinelli \& Moraes (2013). But, in the Distrito Federal, they were only found, so far, in the National Forest of Brasilia, and following the criteria established by the IUCN $(2001 ; 2012)$, both are critically endangered. The status for each species is CR:B1B2ab[iii]C2[ii] and CR:B1B2ab[iii], respectively for $V$. friburgensis and $T$. polystachia, due to the occurrence in an area of $33 \mathrm{~km}^{2}$ and with occupancy lower than $10 \mathrm{~km}^{2}$. Few studies have been carried out in this conservation unit and only the present study, which also focused on Orchidaceae (Lima 2014 pers. comm.), was carried out in its gallery forests. The discovery of these two species may stimulate further studies and help to preserve the FLONA-DF, which suffers great anthropic pressure. 


\section{Acknowledgments}

We thank the Chico Mendes Institute of Biodiversity (ICMBio), for the collection permit to collect in FLONA-DF and Zenilton de Jesus Gayoso Miranda for the critical read of the manuscript.

\section{References}

Baker, J.G. 1887. A synopsis of Tillandsiaea. Journal of Botany 25: 234-246.

BFG. 2015. Growing knowledge: an overview of Seed Plant diversity in Brazil. Rodriguésia 66: 10851113.

Coffani-Nunes, J.V.; Versieux, L.M.; Wanderley, M.G.L. \& Pirani, J.R. 2010. Flora da Serra do Cipó, Minas Gerais: Bromeliaceae - Tillandsioideae. Boletim de Botânica da Universidade de São Paulo 28: 35-54.

CONAP. Consejo Nacional de Áreas Protegidas. 2010. Guía de reconocimiento del género Tillandsia de Guatemala, Guatemala. 113p.

Coser, T.S.; Paula, C.C. \& Wendt, T. 2010. Bromeliaceae Juss. nos campos rupestres do Parque Estadual do Itacolomi, Minas Gerais, Brasil. Rodriguésia 61: 261-280.

Dahlgren, R.M.T.; Clifford, H.T. \& Yeo, P.F. 1985. The families of the monocotyledons. Springer-Verlag, Berlin. 520p.

Espejo-Serna, A. \& Ramírez-Morillo, I. 2010. Flora del Bajío y adyacentes: Bromeliaceae. Inecol 165: 1-145.

Givnish, T.J.; Barfuss, M.H.J.; van Ee, B.; Riina, R.; Schulte, K.; Horres, R.; Gonsiska, P.A.; Jabaily, R.S.; Crayn, D.M.; Smith, J.C.; Winter, K.; Brown, G.K.; Evans, T.M.; Holst, B.K.; Luther, H.; Till, W.; Zizka, G.; Berry, P.E. \& Sytsma, K.J. 2011. Phylogeny, adaptative radiation, and historical biogeography in Bromeliaceae: insights from an eight-locus plastid phylogeny. American Journal of Botany 98: 872-895.

IBGE. 1991. Manual técnico da vegetação brasileira. Departamento de Recursos Naturais e Estudos Ambientais, Rio de Janeiro. 92p.

INMET. 2012. Estações convencionais. Avaliable at $<$ http://www.inmet.gov.br/portal/index. php? $\mathrm{r}=$ home/page\&page=rede_estacoes_conv_ graf>. Access on 1 June 2012.

IUCN - International Union for Conservation of Nature. 2001. Red list categories and criteria: version 3.1. IUCN species survival commission. IUCN, Gland, Switzerland and Cambridge. 30p. Avaliable at $<$ http://www.iucnredlist.org/static/categories criteria_3_1>. Access on 15 December 2015.

IUCN - International Union for Conservation of Nature. 2012. Guidelines for application of IUCN red list criteria at regional and national levels: version 4.0. Switzerland and Cambridge, Gland. 41p.

Felfili, J.M.; Mendonça, R.C.; Walter, B.M.T.; Silva-
Júnior, M.C.; Nóbrega, M.G.G.; Fagg, C.W.; Sevilha, A.C. \& Silva, M.A. 2001. Flora fanerogâmica das Matas de Galeria e Ciliares do Brasil Central. In: Ribeiro, J.F.; Fonseca, C.E.L. \& Silva, J.C.S. (eds.). Cerrado: caracterização e recuperação de Matas de Galeria. Embrapa Cerrados, Planaltina. Pp 195-263.

Filgueiras, T.S.; Nogueira, P.E.; Brochado, A.L. \& Guala, G.F. 1994. Caminhamento: um método expedito para levantamentos florísticos qualitativos. Caderno de Geociência 12: 39-43.

Fiorato, L. 2009. O gênero Tillandsia L. (Bromeliaceae) no estado da Bahia, Brasil. Dissertação de Mestrado. Instituto de Botânica da Secretaria de Estado do Meio Ambiente, São Paulo. 107p.

Gonçalves, E.G. \& Lorenzi, H. 2011. Morfologia vegetal: organografia e dicionário ilustrado de morfologia das plantas vasculares. $2^{\text {a }}$ ed. Instituto Plantarum de Estudos da Flora, São Paulo. 544p.

Govaerts, R.; Luther, H.E. \& Grant, J. 2010. World checklist of Bromeliaceae. Facilitated by Royal Botanical Gardens, Kew. Avaliable at $<\mathrm{http}: / /$ apps.kew.org/wcsp/incfamilies.do>. Access on 18 August 2015.

Kremer, D. 2011. O gênero Tillandsia L. (Bromeliaceae - Tillandsioideae) no estado do Paraná, Brasil. Dissertação de Mestrado. Universidade Estadual de Ponta Grossa, Ponta Grossa. 165p.

León, B. \& Sagástegui, A. 2008. General overview of Tillandsia subgenus Tillandsia in Peru: The threepinnate species and the case of two endemic species. Revista Peruana de Biologia 15: 25-30.

Luther, H.E. 2012. An alphabetical list of bromeliad binomials $\left(13^{\text {th }}\right.$ ed., edited by Bruce Holst and Larry Rabinowitz). Marie Selby Botanical Gardens and Bromeliad Society International, Sarasota. 44p.

Martinelli, G.; Vieira, C.M.; Gonzalez, M.; Leitman, P.; Piratininga, A.; Costa, A.F. \& Forzza, R.C. 2008. Bromeliaceae da Mata Atlântica brasileira: lista de espécies, distribuição e conservação. Rodriguésia 59: 209-258.

Martinelli, G. \& Moraes, M.A. (orgs.). 2013. Livro vermelho da flora do Brasil. Instituto de Pesquisas Jardim Botânico do Rio de Janeiro, Rio de Janeiro. 1100 p.

Mobot. Missouri Botanical Garden. 2015. Tropicos. Avaliable at $<\mathrm{http}: / / \mathrm{www}$.tropicos.org/>. Access on 15 December 2015.

Oliveira-Filho, A.T. \& Ratter, J.A. 1995. A study of the origin of central Brazilian forests by the analysis of plants species distribution patterns. Edinburg Journal of Botany 52: 141-194.

Paris. Muséum National D'Histoire Naturelle. 2015. Consultation des collections. Avaliable at $<\mathrm{https}: / /$ science.mnhn.fr/all/search>. Access on 15 December 2015.

Pontes, R.A.S. \& Agra, M.F. 2006. Flora da Paraíba, Brasil: Tillandsia L. (Bromeliaceae). Rodriguésia 57: 47-61. 
Porembski, S. \& Barthlott, W. 1999. Pitcairnia feliciana: The only indigenous African bromeliad. Harvard Papers in Botany 4: 175-184.

Prado, K.P.C.; Schmidt, E.C.; Steinmacher, D.A.; Guerra, M.P.; Bouzon, Z.L.; Vesco, L.L.D. \& Pescador, R. 2014. Seed morphology of Vriesea friburgensis var. paludosa L.B. Sm (Bromeliaceae). Hoehnea 41: 553-562.

Radford, A.E.; Dickison, W.C.; Massey, J.R. \& Bell, C.R. 1974. Vascular plant systematics. Harper \& Row, New York. 891p.

Reitz, R. 1983. Bromeliáceas e a Malária - Bromélia endêmica. In: Reitz, R. Flora Ilustrada Catarinense. Fasc. BROM. Herbário Barbosa Rodrigues, Itajaí. $559 \mathrm{p}$.

Ribeiro, J.F. \& Walter, B.M.T. 2001. As matas de galeria no contexto do bioma Cerrado. In: Ribeiro, J.F.; Fonseca, C.E.L. \& Silva, J.C.S. (eds.). Cerrado: caracterização e recuperação de Matas de Galeria. Embrapa Cerrados, Planaltina. Pp. 29-47.

Siqueira-Filho, J.A.; Santos, A.M.M.; Leme, E.M.C. \& Cabral, J.S. 2006. Fragmentos da Mata Atlântica de Pernambuco e Alagoas e suas bromélias: distribuição, composição riqueza e conservação. In: Siqueira-Filho, J.A. \& Leme, E.M.C. (eds.). Fragmentos de Mata Atlântica do Nordeste. Biodiversidade, conservação e suas bromélias.
Andrea Jakobson Estúdio, Rio de Janeiro. Pp. 101-131.

Smith, L.B. 1952. Variação em Vriesea friburgensis Mez. Anais Bot. Herb. Barbosa Rodrigues 4: 67-68.

Specieslink. 2015. Dados e ferramentas. Avaliable at $<$ http://splink.cria.org.br/tools/>. Access on 15 December 2015.

Thiers, B. [continuously updated]. Index Herbariorum: A global directory of public herbaria and associated staff. New York Botanical Garden's Virtual Herbarium. Avaliable at $<$ http://sweetgum.nybg. org/ih/>. Accessed on 15 December 2015.

Versieux, L.M. \& Wendt, T. 2006. Checklist of Bromeliaceae of Minas Gerais, Brazil, with notes on taxonomy and endemism. Selbyana 27: 107-146.

Versieux, L.M.; Tomaz, E.C.; Fortunato, M. \& Verola, C. 2013. Anew yellow-flowered ornithophilous Vriesea and an illustrated collection of the bromeliads from Pico Alto, Serra do Baturité, Ceará State, Northeastern Brazil. Phytotaxa 117: 42-50.

Wanderley, M. \& Martins, S. 2007. Bromeliaceae. In: Wanderley, M.; Shepherd, G. \& Giulietti, A. Flora fanerogâmica do estado de São Paulo. Instituto de Botânica, São Paulo. Vol 5, 494p.

Weberling, F. 1992. Morphology of flowers and inflorescences. Cambridge University Press., Cambridge. $405 \mathrm{p}$. 